\title{
Policy and legal framework on protecting children's rights in Latvia and Sri Lanka
}

\author{
Shelomi Perera ${ }^{1, *}$, Ilze Trapenciere ${ }^{1}$, and Lolita Vilka ${ }^{1}$ \\ ${ }^{1}$ Riga Stradins University, Department of Welfare and Social-work, Riga, Latvia
}

\begin{abstract}
The article focuses on comparing policies and legislation, that affect social-work professionals in implementing children's rights of Latvia and Sri Lanka. It attempts to disclose legal framework of the two countries in different socio-cultural, economic and geographical contexts (European and SouthAsian) on implementing children's rights, with base of United Nations Convention on the Rights of the Child (UNCRC). This study analyses local policies, laws, institutional structure and its implementation processes. Policy review has been made by a content analysis, empirical research conducted doing expert interviews $(\mathrm{n}=10)$ focusing on implementation process. Similarities and differences are discussed between two contexts with the standpoint of global perspective of Social work as a global profession. Research results reveal that both countries have sufficient level of policies and legislation to adapt UNCRC, and established specific government bodies for ensuring children's rights. At the same time differences are identified in application of Foster Families, Engagement of children in employments, Children employed as domestic servants, Corporal Punishment to children, in Policy implementation process in Latvia and Sri Lanka.
\end{abstract}

Key words - legal framework, UNCRC, child rights, Latvia, Sri Lanka.

\section{Introduction}

In application of social work, contemporary social work has an inextricable link between Human Rights and social work. Definition of International Federation of Social work (IFSW) clearly stated significance of Human Rights in social work practice: "Social work represents a rights-based profession and an academic discipline that promotes social change and development, social cohesion, and empowerment and liberation of people" (IFSW, 2014) [1]. Human Rights of children are identified and documented by UNCRC (1989). This presents uniformity and consistency for identifying and achieving children's rights. Ways that countries adopt UNCRC recommendations are varied country to country according to several factors. In Latvia, as a country in Europe, and Sri Lanka as a country in South Asia, legislation and policy framework could be different. On the other hand, there can be similarities in legal framework, and implementation process. The Republic of Latvia has bound to the UNCRC by ratifying it (1992). Latvia has provided necessary legal allocations by adopting UNCRC recommendations by imposing legislation and policies: "Latvia has ratified UNCRC, and the Convention became binding to Latvia starting from May 14, 1992", Trapenciere (2015) [2].

\footnotetext{
*Corresponding author: shelomiperera@rsu.edu.lv
} 
Sri Lanka is a state party to UNCRC, and fundamental rights of the citizens are statutory by the 1978 constitution and legislation.

Research problem - to explore legal provisions on accomplishing children's rights to adopt UNCRC in two different socio-cultural and economic contexts: Latvia and Sri Lanka.

Research objectives:

1. Analyse legal framework and the implementation of UNCRC recommendations.

2. Find out similarities and differences of socio-cultural backgrounds related to accomplish children's rights.

Research methods - A content analysis is used to analyse and compare policies and legislation. Empirical data was collected performing semi-structured in-depth interviews.

\section{Children's rights: From global to local contexts}

Children's rights as a part of Human Rights, with its specific demand of universally applicable ideas and values of humanity, echoes across cultures, traditions and geographical regions representing importance of uniting to create a peaceful and sustainable world. After the Universal Declaration of Human Rights (UDHR), rights of persons are specified. There are other conventions and declarations introduced on behalf of vulnerable groups such as children, persons with disabilities and elderly.

Regardless of its resilient application power, Human Rights can have different interpretations in different contexts. "The best-known statement of Human Rights, the Universal Declaration of Human Rights, though representing perhaps one of the more remarkable human achievements of the twentieth century, should not therefore be seen as expressing a universal and unchanging truth" (Ife 2008) [3]. This application could be spread over on children's rights as well.

However, Human Rights are endorsed by people in diverse cultural and ideological backgrounds, and have been used rhetorically in support of different and contradictory grounds. Human Rights are Universalist discourse, based on ideas of shared humanity in global citizenship, but it can be contextualized within the background of culture and society. Nonetheless, not all cultural practices or policies place the same value on Human Rights. It is a situation that may result in conflict for social workers, who have ethical obligation to advocate for Human Rights, as well as to be sensitive to their clients' cultural contexts. "Human Rights are commonly constructed as universals, and yet the era of post-modernity is seeing the increasing fragmentation and localization of multiple narratives and an increasing emphasis on context and relativism. Confronting such universal/contextual dualisms, and exploring how social work theory and practice can understand Human Rights as both universal and contextual, therefore a major challenge for Human Rights-based social work" (Ife 2008).

Human Rights approach to social work always entails clients to have maximum grant into decisions on subject of their future. This is mostly expected towards clients who are vulnerable and powerless, such as children. The universal idea of understanding 'the rights of the child' may controversial in different contexts. Although child welfare and wellbeing are main parts of social work, social workers could encounter challenges in competing claims of rights on sensitive issues in particular cultural grounds: "We are nothing without our cultural context. It is the culture that meaning to life, and it is the culture that determines a good deal of human behaviour" (Jenks, 1993) [5].

\section{Convention on the rights of the child}

United Nations Convention on the Rights of the Child (UNCRC) identifies children's rights. It has identified need of special protection on achieving rights of children as stating 
"Bearing in mind that, as indicated in the Declaration of UNCRC Convention on the Rights of the Child, the child, by reason of his physical and mental immaturity, needs special safeguards and care, including appropriate legal protection before as well as after birth" UNCRC (1989) [6]. UNCRC recognizes international collaboration for improving social wellbeing, achieving human rights, and enhancing quality of living of children globally, particularly in countries, which cooperate to the convention. "The UNCRC spells out basic human rights that children everywhere have: right to survival; to develop to the fullest; to protection from harmful influence, abuse, and exploitation; and to participate fully in family, cultural, and social life" (Katiuzhinsky \& Okech, 2012; UNICEF, 2005) [7]. The Convention consolidates fundamental human rights of all children. All human beings below age of 18 are considered as children. UNCRC outlines international standards for defining children's rights, and a framework of actions. UNCRC provides universality and uniformity at defining human rights of children.

\section{Research method}

Methodology used in this research was mixed method: document analysis of legislation and policies, and qualitative interviews. The study was desk-based content analysis to analyse and compare policies and legislation. Semi-structured interviews with 10 experts were used for obtaining empirical data.

First stage was to collect relevant legislation and policies that were passed by the governing bodies of regarding Articles of $\operatorname{UNCRC}(3,6,9,19,20,27,28,31,32)$. Second stage was collecting qualitative and quantitative data from expert interviews and survey and analysed contents with standpoint of the uniformity of universal perspective of children's rights in accordance with UNCRC.

Research sample - for this study, purposive sampling is utilized. Legislation, Acts, policies, Action Plans, and Cabinet Regulations pertinent to children's rights, imposed after the countries ratified UNCRC and amendments of previous legislations were analysed. Selected experts for participating in interviews are holding high rank positions in related fields for the study. They have 20-25-year experience and comprehensive knowledge of legal framework, decision-making procedure and profound idea in the overall of their working field. Thematic analysis was used to organize the data of qualitative interviews. This process provides an easily interpretable method in qualitative research.

\section{Legal framework on children's rights, Republic of Latvia}

UNCRC became binding to Latvia since ratification in 1992. After that key step in child protection, welfare and development have placed greater priorities by legislation. Main national legal framework for children's rights is built upon Law on the Protection of the Child's Rights (1998, with Amendments) [8]. The objective of the Law is to determine rights and freedoms of children and their protection, regulates rights and responsibilities of parents and guardians (Art.2). It defines a child as "a person under age of 18, except cases when he/she is married (Art.3.1)." The purpose is to set out the rights and freedoms of a child. Hence, by concerning a child as physically and mentally immature person, he/she needs special protection and care. This law regulates obligations and accountabilities of parents and other persons, state and local governments about ensuring children's rights and emphasizes protection of child rights is an integral part of the state policy. Cabinet Regulation No.857 Regarding Social Guarantees for an Orphan and a Child Left without Parental Care who is in Out-of-Family Care as well as After the Termination of Out-of-Family Care (2005) [9], determines social 
guarantees for an orphan or a child left without parental care who receives out-of-family care (with a custodian, foster family or in a childcare institution). Youth Law (2008) [10] - purpose of this Law is to improve the life quality of young people, persons from 13 to 25 years of age, by promoting initiatives, participation in decision-making and social life, as well as by supporting youth work (Art $1 \& 2$ )." The Law discusses seven basic principles of the Youth policy, including participation, availability of information, principle of equal opportunities, principle of observance, principle of favourable economic preconditions, principle of integration and principle of international cooperation and mobility (Article-3). The Education Law (1998) [11] expects to "ensure that every resident of Latvia has the opportunity to develop his/her mental and physical potential, to become an independent a fully developed individual, a member of the democratic State and society of Latvia. A person ensured the opportunity to acquire knowledge and skills, in the life for moral, aesthetic, intellectual and physical development, by promoting skilful and socialized individual." The Labour Law (enforced 2001) [12] regulates "restrictions and liability of employment type, amount, time and place of discharge, obligations, remuneration for persons under 18, working time for persons under 18 years and part-time work (Art. 37)." It defines that a child cannot be permanently employed. In exceptional cases, children from age 13 can be employed in a part-time job during leisure time if there is written consent from one parent or custodian. The job must not hinder child's education. Duties should be simple and light. Children shall be employed only after compulsory medical examination.

Requirements for Social Service Providers (2017) [13] point "requirements for service providers of long-term social-care and social rehabilitation institution for children." Law on Social Services and Social Assistance (2002) [14] determines "principles for social-work, care, assistance and rehabilitation and persons eligible for such services as well as principles of financing social assistance". It also determines "requirements that social care, social rehabilitation and social-work service providers must comply." Procedures for Granting and Paying Remuneration for the Performance of Foster Family Duties (2009) [15] "Determine and regulate children to receive social guarantees in foster care." The Ombudsman's Office of Latvia (2007) [16] is an independent Human Rights institution in charge of protection of rights of every inhabitant of Latvia, including children. The Department of Children's Rights promotes children's rights and reviews complaints. The Civil Law (1937, Amendments) [17] determines "guardianship and trusteeship of children, legal relations associated with the paternity breaking down of a marriage, duties as between parents and children, personal relations of parents and children." (Article-177). The State Inspectorate for Protection of Children's Rights (established in 2005) [18] ensures supervision and control of compliance with regulatory enactments in field of protection of children's rights and scope of Custody Courts. It supervises and controls activities of municipalities and other NGOs of children's rights.

\section{Legal framework on children's rights, Sri Lanka}

Sri Lanka signed the UNCRC on 26th January 1990 and ratified on 12th July 1991. As a follow-up to UNCRC, government of Sri Lanka formulated Children's Charter in 1992 (Ministry of Women \& Child Affairs and Social Security 2019) [19]. The country has introduced following legislation: National Child Protection Authority Act, No.50 (1998) [20] which "provides for establishment of national child protection authority to formulate a national policy on prevention of child abuse and protection." Age of Majority Ordinance No.7 of 1865 (amendment) Act No.17 of (1989) [21] "defines age of eighteen as to legal age of majority." Prevention of Domestic Violence Act: Act No.34 (2005) [22] "provides for prevention of any act of domestic violence against children." The Civil Aspects of International 
Child Abduction Act No.10 (2001) [23] deal with protection of children against negative effects of wrong removal or retention internationally. Adoption of Children Ordinance, 1941; amended (1992) [24] "provides procedures for adoption of children and registration of persons who are not natural parents of a child but have the care, custody or control of a child in District courts." Maintenance Act, (1999) [25] describes "Maintenance of children who are unable to maintain themselves." Tsunami (Special Provisions) Act, No.16 (2005) [26] "makes provision concerning care and custody of children who have been orphaned or left with a single parent, consequent to tsunami." Penal Code (ordinance) No.2, 1883 amendment Act, No.10 (2018) [27] "introduced new offences related to children, applicable punishments and matters relating to offences." Obscene Publications Ordinance No.4 (1927), amended Act No.12 (2005) [28] "Offences relating to obscene publications are set out in this Ordinance. Children under 18 are prohibited from keeping obscene publications." Citizenship (Amendment) Act No.16 (2003) [29] - this act "allowed for obtaining nationality of children in Sri Lanka from both parents (not only from the father)." International Covenant on Civil and Political Rights (ICCPR) Act No.56 (2007) [30] emphasizes "importance of best interest of child in all matters and decisions taken by the court, administrative authorities and legislative bodies regarding child." Corporal Punishment (Repeal) Act No.23 (2005) [31] "repealed Corporal Punishment Ordinance and also omitted sentence of whipping where it is included as part of a sentence to be imposed by courts in respect of any offence committed under any written law." However, this Act repeals corporal punishment in prisons under the Prisons Ordinance 1877 (amended 1939). Drug Dependent Persons (Treatment and Rehabilitation) Act No.54 (2007) [32] describes "process, in case of drug or substance dependent incident of a child." Prohibition of Ragging and other forms of violence in Educational Institutions Act No.20 (1998) [33] considers "eliminating ragging, violent and cruel inhuman treatment from educational institutions to children." Employment of Female Young Persons and Children's Ordinance No.47 (1956) (Amendment) Act No.47 (1999) [34] has strengthened child labour law by "increasing minimum age of employment from 12 to 14 years, and prohibiting employment of children under 14 while enhancing sentence for violation of this provision." Evidence (Special Provisions) Act No.32 (1999) [35] provides for court to receive evidence of a child without causing an oath or an affirmation to be administered to such a child. This Act also provides for video recorded interview with a child to be led in evidence in cases relating to child abuse. Marriage Registration (Amendment) Act No.18 (1995) [36] rises minimum age of marrying to 18 years. Assistance to and Protection of Victims of Crime and Witnesses Act No.4 (2015) [37] ensures "protection for child victims and child witnesses of crimes, rights to a mechanism for reparation and rehabilitation of survivors of crime, duties and responsibilities of judicial and public officers toward rights violations and associated penal sanctions." Mediation Boards (Amendment) Act No.4 (2011) [38] considers "mediation for commit theft of a child under age 18." Births and Deaths Registration Act No.17 of 1951 (amendment) Act No.12 (2005) [39] is the law relating to "the registration of births, deaths and still-births."

Children and Young Persons Ordinances No.48 (1939) (amended) Act No.47 (1956) [40] - "Establishment of juvenile courts, the jurisdiction and procedure of juvenile courts, special provisions apply to all courts concerning children's preliminary proceedings." Constitution of Sri Lanka (1978) [41] ensures rights of children in Sri Lanka. Children and Young Persons (Harmful Publications) Act No.48 (1956) [42] protects children from harmful publications, selling and having in possession of obscene books, photographs and films. Administration of Justice (Amendment) Law No. 25 of 1975 - Sect. 3 [43] "Civil Courts Procedures to actions by a minor, to actions against a minor, to take charge of a minor, to take charge of estate of a minor, custody of a minor and compulsory judicial settlement of accounts of a minor." Education Ordinance No 31 (1939) [44] the national law on education contained in 
this ordinance and also Compulsory Attendance of Children at School Regulation No. 1 of 2015, provides for compulsory education from 5 to 16 years of age. The Factories Ordinance No.45 (1942) [45] states minimum age of children to be employed in factories and working hours for persons between 18-16 daily and per week. Youthful offenders (Training Schools Ordinance) No.28 (1939) [46] establishing training and detention institutions for juvenile delinquents Registration of Domestic Servants Ordinance No.28 (1871) (amended) Act No.18 (1936) [47] provides for registration of domestic servants. Under current law children over 14 years of age can be employed as domestic servants. Houses of Detention Ordinance (1907) (Amendment) Act No 25. (1955) [48] - establishment of detention houses for vagrants and street children. Shop and Office Employees Act No.19 (1954) (Amendment) Act No. 44 (1985) [49] states "minimum age for employment in a shop or office is 14 years and they are not allowed to work before 6 a.m. or after 6 p.m."

\section{Similarities and differences of policy framework and implementation}

In comparison, similarities have been identified - sufficient level of policies and legislation to adapt UNCRC. There are enough legal atmospheres to accomplish children's rights, and both countries established specific government bodies for ensuring children's rights. Considerable differences have also been noted. Foster Families: Latvia - there is a Cabinet Regulation to determine children receive social guarantees in foster care. Sri Lanka - the concept 'Foster Families' has not been included to the legal context. Policies only provide procedures for adoption of children for persons who are not natural parents of a child. Engagement of children in employment: Latvia - Labour Law regulates restrictions and liability of employment type, time and place of discharge of employee's obligations, part-time work remuneration for person's minimum age 13 years, and it needs the consent of parent or guardian. Sri Lanka - legislation defines 14 years as minimum age when children can engage in employments. Children employed as domestic servants: Sri Lanka - there is legislation determining registration of children over age 14 who can be employed as domestic servants. Latvia - concept of using children as domestic servants is unfound in legislation. Corporal Punishment: Sri Lanka - although Corporal Punishment (Repeal) Act repeals corporal punishment in prisons, there is no prohibition to other penal institutions such as remand homes, approved homes and certified schools. It is a minus point about repealing the corporal punishment. Latvia - this concept is unfound in legislation.

Responds of participants of interviews and survey have revealed differences in policy implementation. Regarding decision-making power of social workers expert participants in Latvia show, that majority of social workers are responsible for preparing and providing necessary information and materials for authorities. Social workers mostly work in institutions, and they depend on organization's decisions. "The social worker depends on the institution where they work. The social worker affects very much the decision of organization they represent, but, anyway, the social worker is not independent.' (L2).

Social workers can make decisions in capacity of supporting families they do not have engaged in political level or macro level in decision-making. Relatively, social workers do not possess enough power, and the orphans' court retains more power in decision-making. "Social work professionals have a decision-making power in consideration whether their judgment brings a risk of harm when making a decision for child protection" (L3).

"The social workers can make decisions in helping families and informing further authorities. ... they are subordinated under municipalities” (L4).

In Sri Lanka, social workers have significantly lower decision-making power. Officers of Probation and child-care services and child protection authority engage in decision-making 
from ground level, not social workers. "In decision-making power probation officers make decisions. They do investigation, develop a plan, and implement it. Sometimes medical practitioners are involved" (SL1).

"The legally bounded Person of child rights is child rights promotion officer. In Sri Lanka, child rights promotion officer is not a social worker or a person trained in social work" (SL3).

Even as a body, Association of professional social workers also does not have a power in decision-making. "We have a social work body. We call it Sri Lanka Association of Professional Social workers, but SLAPSW is not powerful. So, there is a barrier to talk acutely about child rights through the social work profession" (SL2).

There are considerable obstacles from cultural and religious impact on implementing the policies and legislation in Sri Lanka "UNCRC recommendations become problematic when it comes to implementing within Sri Lanka. The political and cultural background of the country has an impact" (SL3).

Parents and adults' attitudes - "There is so much of parents' influence on children. So children do not have freedom to make their own decisions" (SL1).

There are considerable limitation and obstacles from cultural and religious backgrounds for implementing policies regarding UNCRC recommendations. "One thing is that we are a multi-cultural country; every culture has its traditions and customs. Some people have a negative attitude about cultural aspects and practices of others. Because of that, problems appear in society" (SL2).

Within the research, we gathered information about parents and teachers' attitude to imposing physical punishments to children. Parents' attitude: In Sri Lanka, majority of parents think they should give physical punishments to their children, and in Latvia - only few of parents think that children should be given some physical punishments. Teachers' attitude: In Sri Lanka, majority of teachers consider that children should be physically punished. In Latvia, majority of teachers believe children should not be punished physically.

\section{Conclusions}

Even though Sri Lanka and Latvia have different contexts, both countries sufficiently adopted UNCRC in their legislations and incorporated with their institutions. In contrast, there are key differences in policy implementations.

Analysis of legislation and policy framework and implementation has identified certain similarities and differences. As for similarity, both countries meet the requirement to take all appropriate measures necessary to implement UNCRC recommendations, and there is a sufficient level of regulations. Countries sufficiently cover focal rights of children such as best interests of the child, life, survival and development, separation from parents, protection from violence, abuse and neglect, children unable to live with their family, right to education, child labour.

Differences were noted in the two contexts: in Latvia, there is a Cabinet Regulation to determine that children receive social guarantees in foster care. In Sri Lanka the concept 'Foster Families' has not been included in legal context and only provides procedures for adoption of children. When engagement of children in employment is compared, in Latvia, employees' minimum age is 13 years, and it needs consent of guardians. In Sri Lanka, the minimum age of children employment is 14 years. In Sri Lanka, the legislation determines registration of children over the age 14 when they can be employed as domestic servants, whereas Latvia does not state any legislation allowing use of children as domestic servants.

In Sri Lanka, Corporal Punishment (Repeal) Act repeals corporal punishment only in prisons under the Prison Ordinance. It is needed more consideration. This concept is unfound in 
Latvian legislation. There are considerable differences in policy implementation and decision making power of social workers in socio-cultural aspects in both countries.

\section{References}

[1] IFSW, Global Definition of the Social-work Profession (2014), www.ifsw.org/what-issocial-work/global-definition-of-social-work/ [accessed 19 May 2020]

[2] I. Trapenciere, Evaluation of legislation, policy and practice on child participation in the European Union (EU) - Country report-Latvia (2015). http://publications.europa.eu/ resource/cellar/3e1ce842-b9fa-46d0-8bd0-f465a9c8eb78.0001.01/DOC \1[ [accessed 19 May 2020]

[3] J. Ife, Human-Rights and social-work towards rights-based practice (Cambridge Univ. Press, Cambridge 2008)

[4] ibid

[5] C. Jenks, Culture (Routledge, London 1993)

[6] UN General Assembly, Convention on the Rights of the Child, UN. Treaty Series 1577 (1989), https://www.refworld.org/docid/3ae6b38f0.html [accessed 19 May 2020]

[7] A. Katiuzhinsky, D. Okech, Human rights, cultural practices, and state policies: Implications for global social work practice and policy. Int. J. of Soc.Welf. 23 (2012)

[8] Saeima, Law on the Protection of the Child Rights (1998) https://likumi.lv/ta/en/en/id/ 49096-law-on-the-protection-of-the-childrens-rights [accessed 19 May 2020]

[9] Cabinet of Ministers, Regulations No.857 on Social Guarantees for the Orphan or the Child Left without Parental Care (2005), https://likumi.lv/ta/en/en/id/121592 [accessed 19 May 2020]

[10] Saeima, The Youth Law (2008), https://likumi.lv/ta/en/en/id/175920 [accessed 19 May 2020]

[11] Saeima, The Education Law (1998), https://likumi.lv/ta/en/en/id/50759-education-law [accessed 19 May 2020]

[12] Saeima, Labour Law (2001), https://likumi.lv/ta/en/en/id/26019-labour-law [accessed 19 May 2020]

[13] Cabinet of Ministers, Regulations No. Requirements for Social Service Providers (2017), https://likumi.lv/ta/en/en/id/291788-requirements-for-social-service-providers [accessed 19 May 2020]

[14] Saeima, Law on Social Services and Social Assistance (2002), https://likumi.lv/ta/en/en/id/68488-law-on-social-services-and-social-assistance [accessed 19 May 2020]

[15] Saeima, Granting and Paying Remuneration for the Performance of Foster Family Duties (2009), https://likumi.lv/doc.php?id=202717 [accessed 19 May 2020]

[16] Ombudsman of the Republic of Latvia. Annual Report 2017, http://www.tiesibsargs.lv/ uploads/content/legacy/2017 \annual $\_$report $\_$summary $\backslash 1523624612$.pdf $\quad$ [accessed 19 May 2020]

[17] Saeima, Civil Law. First Part. Family Rights. Law of the Republic of Latvia (1993), https://likumi.lv/ta/en/en/id/225418-the-civil-law [accessed 19 May 2020]

[18] Cabinet of Ministers, Cabinet Regulation No.898 (2005), https://likumi.lv/ta/en/id/ 122431-by-laws-of-the-state-inspectorate-for-protection-of-childrens-rights [accessed 19 May 2020]

[19] MoCW, UNCRC (2019), http://www.childwomenmin.gov.lk/institutes/dep-probationand-child-care-services/child-rights/crc [accessed 19 May 2020] 
[20] Parliament of Sri Lanka, Sri Lanka National Child Protection Authority Act, No.50 of 1998 (Gov.press, Colombo,1998)

[21] Parliament of Sri Lanka, Age of Majority Ordinance No.7 of 1865, Gazette Sri Lanka, 17 Feb. 2017

[22] Parliament of Sri Lanka, Prevention of Domestic Violence Act No.34 of 2005 (Gov.press, Colombo, 2005)

[23] Parliament of Sri Lanka, The Civil Aspects of International Child Abduction Act No.10 of 2001 (Gov. press, Colombo, 2001)

[24] Parliament of Sri Lanka, Adoption of Children Ordinance, 1941; amended (1992) (Gov. press, Colombo, 1992)

[25] Parliament of Sri Lanka, Maintenance Act, No.37 OF 1999 (Gov. press, Colombo, 1999)

[26] Parliament of Sri Lanka, Tsunami (Special Provisions) Act, No.16 of 2005 (Gov. press, Colombo, 2005)

[27] Parliament of Sri Lanka, Penal Code (Ordinance) No.2 of 1883 Amendment Act No.10 of 2018 (Gov. press, Colombo, 2018)

[28] Parliament of Sri Lanka, Obscene Publications Ordinance No.4 of 1927, Amended Act No. 12 of 2005 (Gov. press, Colombo, 2005)

[29] Parliament of Sri Lanka, Citizenship (Amendment) Act No.16 of 2003 (Gov. press, Colombo, 2003)

[30] Parliament of Sri Lanka, International Covenant on Civil and Political Rights (ICCPR) Act No.56 of 2007 (Gov. press, Colombo, 2007

[31] Parliament of Sri Lanka, Corporal Punishment (Repeal) Act No.23 of 2005 (Gov. press, Colombo, 2005)

[32] Parliament of Sri Lanka, Drug Dependent Persons (Treatment and Rehabilitation) Act No.54 of 2007 (Gov. press, Colombo, 2007)

[33] Parliament of Sri Lanka, Prohibition of Ragging and Other Forms of Violence in Educational Institutions Act No.20 of 1998 (Gov. press, Colombo, 1998)

[34] Parliament of Sri Lanka, Employment of Women, Young Persons and Children, the Factories and the Shop and Office Employees (Regulation of Employment and Remuneration) (Amendment) Act, No. 32 of 1984 (Gazette. August 1984)

[35] Parliament of Sri Lanka, Evidence (Special Provisions) Act No.32 of 1999 (Gazette October 1999)

[36] Parliament of Sri Lanka, Marriage Registration (Amendment) Act. No. 11 of 2001 (Gov. press, Colombo, 2001)

[37] Parliament of Sri Lanka, Assistance to and Protection of Victims of Crime and Witnesses Act No.4 of 2015 (Gov. press, Colombo, 2015)

[38] Parliament of Sri Lanka, Mediation Boards (Amendment) Act No.4 of 2011 (Gov. press, Colombo, 2011)

[39] Parliament of Sri Lanka, Births and Deaths Registration Act No.17 of 1951 (Amendment) Act No.12 of 2005 (Gov. press, Colombo, 2005)

[40] Parliament of Sri Lanka, Children and Young Persons Ordinances No.48 of 1939 (Amended by) Act No.02 of 1978 (Gov. press, Colombo, 1956)

[41] Parliament Secretariat, The Constitution of Democratic Socialist Republic of Sri Lanka of 1978 (Gov. press, Colombo, 1978)

[42] Parliament of Sri Lanka, Children and Young Persons (Harmful Publications) Act No.48 of 1956 (Gov. press, Colombo, 1956)

[43] State Council of Ceylon, Administration of Justice (Amendment) Law No. 25 of 1975 (Gov. press, Colombo,1975) 
[44] State Council of Ceylon, Education Ordinance No.31 of 1939 (Gov. press, Colombo, 2008)

[45] State Council of Ceylon, The Factories Ordinance No.45 of 1942 (Gov. press, Colombo, 2008)

[46] State Council of Ceylon, Youthful Offenders (Training Schools Ordinance) No.28 of 1939 (Gov. press, Colombo, 2008)

[47] State Council of Ceylon, Registration of Domestic Servants Ordinance No.28 of 1871 (Amended) Act No.18 of 1936 (Gov. press, Colombo, 2008)

[48] Parliament of Sri Lanka, Houses of Detention Ordinance of No.05 of 1907 (Amendment) Act No 25. Of 1955 (Gov. press, Colombo, 1955)

[49] Parliament of Sri Lanka, The Shop and Office Employees Act No.19 of 1954 (Amendment) Act No 44 of 1985) (Gov. press, Colombo, 1985) 